\title{
LATVIJAS MINERĀLĀS IZEJVIELAS EKO-KERAMIKAS IZSTRĀDEI
}

\author{
GAIDA SEDMALE ${ }^{*}$, MĀRIS RUNDĀNS ${ }^{2}$, MĀRTIN̦Š RANDERS ${ }^{3}$, \\ INGUNDA ŠPERBERGA ${ }^{4}$, ANDRIS CIMMERS ${ }^{5}$ \\ ${ }^{1-5}$ Rìgas Tehniskā universitāte, Silikātu materiālu institūts, Latvija
}

Kopsavilkums. Darbā dots ieskats par iespējām izmantot Latvijas minerālās izejvielas kā bāzi vai piedevu keramikas materiālu (eko-materiālu) izstrādei ar dažādu pielietošanas aspektu, to skaitā parādīt iespēju šo materiālu ieguves tehnologisko procesu optimizēšanai virzībā uz to apdedzināšanas temperatūras samazināšanu, līdz ar to reducējot kaitīgu gāzveida izmešu nonākšanu vidē. Parādīti darbu rezultāti laika periodā no 2007. g. līdz 2017. g. Tiek apskatīti un analizēti sekojoši pētījumi:

- neapstrādāta māla pielietošana atkritumu deponēšanas vietu noblīvēšanai;

- dal̦ēji dehidratizēta māla pielietošana $\mathrm{Cr}^{3+}, \mathrm{Cr}^{6+}, \mathrm{Zn}^{2+}$ un $\mathrm{Cu}^{+}$jonu sorbcijai, kas veidojas galvanisko procesu notekūdenos; poru saturošas augsttemperatūras keramikas izstrāde no jauktiem izejvielu maisījumiem, kas nodrošina pietiekamu gāzveida fāzes izveidošanos keramikas apdedzināšanas procesā, veidojot poras, lai pielietotu par filtrēšanas/attīīššnas materiālu;

- illīta māla piedevu izmantošana, lai pazeminātu augsttemperatūras blīvas keramikas sak̦epināšanas/apdedzināšanas temperatūru, iegūstot ilgspējīgu mehāniski un termiski izturīgu produktu; kā arī tehnoloǵiskie procesi, kas nodrošina porainas, siltumu izolējošas keramikas materiāla ieguvi pie pazeminātām temperatūrām (ǵeopolimēru metode).

Atslēgas vārdi - atkritumu deponēšana, jonu sorbcija, termiskā trieciena izturība, kordierīta keramika.

\section{Ievads}

Jau pirms 200 gadiem sakarā ar rūpniecības attīstību, it seviški rietumu pasaulē, vienlaicīgi sākās pieaugošs apdraudējums dabai un cilvēku veselībai. Tādēl aktuāls kḷūst jautājums par arvien pieaugošā

\footnotetext{
* Korespondējošais autors. E-pasts: gaida-maruta.sedmale@rtu.lv
} 
piesārṇojuma samazināšanu vai novēršanu. Tikai aptuveni pirms 50 gadiem visa veida piesārn,ojums sāka tikt uztverts ne vien kā lokāla, bet arī kā globāla problēma [1]. Vēl divdesmitā gadsimta astoṇdesmitajos gados viens no svarīgākiem dabas aizsardzības tematiem bija skābais lietus, kam par iemeslu bija $\mathrm{SO}_{2}$ izmeši atmosfērā, ko veidoja galvenokārt akmen,oglu sadegšanas produkti. Vēlāk, attīstoties plašai auto izmantošanai, piesārn,ojums saistījās ar $\mathrm{NO}_{x}$ gāzu emisiju. Šodien šīs problēmas visumā ir atrisinātas. Piemēram, auto izplūdes gāzes tiek attīrītas, pilnveidojot to sadegšanas procesu, kā arī izmantojot filtrus un katalizatorus.

Šobrīd aktualitāti iegūst enerǵijas resursu izsīkums, kā arī klimata izmain,as $\mathrm{CO}_{2}$ izmešu rezultātā. Līdz ar to svarīgs ir jautājums par alternatīviem enerǵijas avotiem, piemēram, saules enerǵijas, atkritumu izmantošana u. c. Šajā aspektā zinātniskajā literatūrā ir pietiekami daudz publikāciju par tā sauktajiem eko-materiāliem, kurus autors [2] iedala trijās lielās grupās:

- funkcionālie (piesārṇojuma novēršanai, alternatīvas toksiskām vielām, $\mathrm{CO}_{2}$ sorbenti),

- enerǵiju taupoši materiāli (materiāli atkritumu pārstrādei, materiāli "zaḷām" enerǵijas sistēmām),

- sociāli-ekologiskie materiāli (viegli reciklējami, dabai draudzīgi materiāli).

Savukārt autors [3] raksta, ka kritērijiem, kas nosaka dotā materiāla piederību eko-materiālu grupai, tiek izvirzīti četri nosacījumi:

- augsta eko-efektivitāte, lai sniegtu sabiedrībai ilgtspējīgu nodrošinājumu,

- augsta eko-efektivitāte tiek realizēta optimāli kombinējot dabas aizsardzības, resursu un tehnikās lietderības aspektus saistībā ar dzīves ciklu,

- it sevišķ eko-materiālam ir jāasociējas ar minimālu risku attiecībā uz veselību, minimālu dabai kaitīgu izmešu veidošanu, minimālu dabas noplicināšanu un optimālu fizikālu un tehnisku īpašību nodrošinājumu, tas ir, katram izstrādātam konkrētam eko-materiālam visā tā dzīves ciklā jāatbilst dabas aizsardzības, resursu, sociāliem, sabiedrības un ekonomiskiem aspektiem.

N̦emot vērā augstāk minēto, eko-keramikas materiāli no pārējiem atšķiras ar temperatūras izturības stabilitāti oksidējošā atmosfērā vai citos l̦oti skarbos dabas apstākḷos. Bez tam keramikas materiāliem piemīt daudz funkcionālu īpašību, piemēram, spēja akumulēt radioaktīvos atkritumus to uzglabāšanas vietās, spēja filtrēt (attīrīt) dīzeḷdegvielas sadegšanas produktus dīzel̦dzinējos, uzlabot ūdens kvalitāti, to attīrot no dažāda veida piemaisījumiem, u. c. Tikai keramikas eko-materiāliem vien ik gadus ir veltīts vairāk nekā tūkstoš publikāciju [3]. 
Šì darba mērkịis ir dot ieskatu par iespējām izmantot Latvijā plaši izplatītās mālu iegulas (arī dolomītu) gan kā bāzi, gan kā piedevu keramikas materiālu (eko-materiālu) izstrādei ar dažādu pielietošanas aspektu, kā arī uzlabot šo materiālu ieguves tehnologisko procesu virzībā uz to apdedzināšanas temperatūras samazināšanu, līdz ar to reducējot kaitīgu gāzveida izmešu nonākšanu vidē.

Šajā nolūkā laika periodā no 2007. g. līdz 2017. g. ir apskatīti:

- neapstrādāta māla pielietošana atkritumu deponēšanas vietu noblīvēšanai;

- dalẹji dehidratizēta māla pielietošana $\mathrm{Cr}^{3+}, \mathrm{Cr}^{6+}, \mathrm{Zn}^{2+}$ un $\mathrm{Cu}^{2+}$ jonu sorbcijai, kas izveidojas, piemēram, galvaniskos procesos;

- poras saturošas augsttemperatūras keramikas izstrāde no jauktiem izejvielu maisijumiem, kas nodrošina pietiekamu gãzveida fāzes izveidošanos keramikas apdedzināšanas procesā un akumulēšanos keramikas matricā, veidojot poras. Šos materiālus plānots pielietot kā filtrēšanas/attīrīšanas materiālus (piemēram, atejošo dūmgāzu, metālu kausējumu attīrīšanai u. c.);

- dabas minerālo izejvielu - illītu māla piedevu izmantošana, lai pazeminātu augsttemperatūras blīvas keramikas saķepināšanas/ apdedzināšanas temperatūru, līdz ar to samazinot gāzveida produktu (galvenokārt $\mathrm{CO}_{2}$ ) akumulēšanos atmosfērā un iegūstot ilgspējīgu, mehāniski un termiski izturīgu produktu;

- tehnologiskie procesi, kas nodrošina porainas, siltumu izolējošas keramikas ieguvi pie pazeminātām temperatūrām (ǵeopolimēru metode).

\section{Māla pielietošana eko-sistēmās}

\section{A. Atkritumu deponēšanas vietu noblīvēšana}

Lai veidotu māla slāni atkritumu deponēšanas vietās, tiek izmantoti mazāk kvalitatīvi devona virsējie māla slāṇi no Kupravas atradnes, kas satur nedaudz paaugstinātu smilšaino frakciju. Dominējošā īpašîba, kurai jāpiemīt mālam, šajā gadījumā ir caurlaidība attiecībā uz lietus ūdeniem, kura noteikta pēc DIN 18130 vienkāršotā caurlaidības noteikšanas iekārtā. Saskaṇā ar norādītām normām un tajās doto caurlaidības aprēḳināšanas formulu kā izejas dati tiek pielietoti šādi mālus raksturojoši lielumi: blīvums, mālu masas mitruma saturs pirms un pēc mērījuma, parauga šķērsgriezuma laukums, ūdens līmen̦a samazinājums laika vienībā [6], [7].

Atkritumu deponēšanas vietās parasti pielieto vairākslāṇu pārklājumu gan no virspuses, gan no apakšpuses, kas norobežo atkritumus no gaisa aǵentu (lietus ūdens, gaisa gāzveida sastāvdaḷu, kā piemēram, 


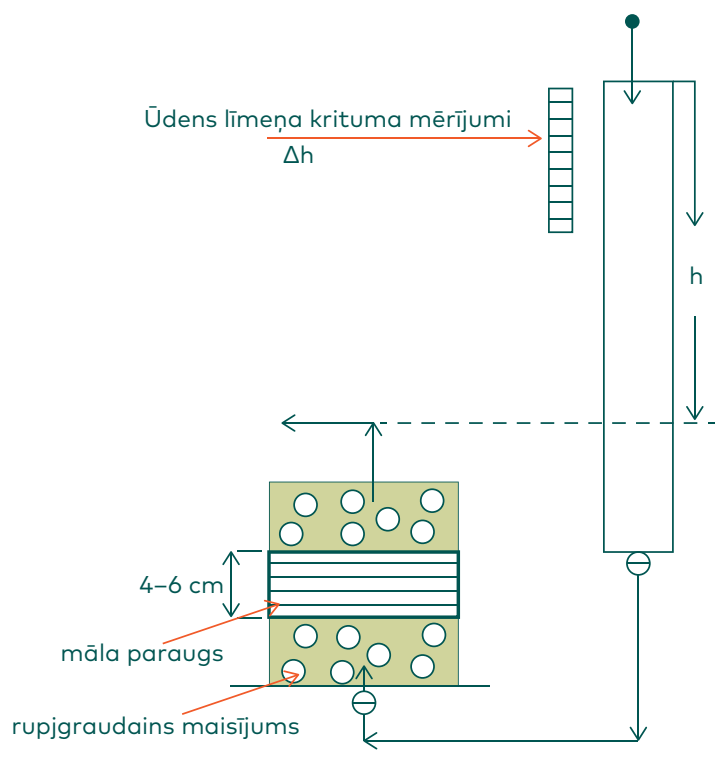

Latvijas minerālās

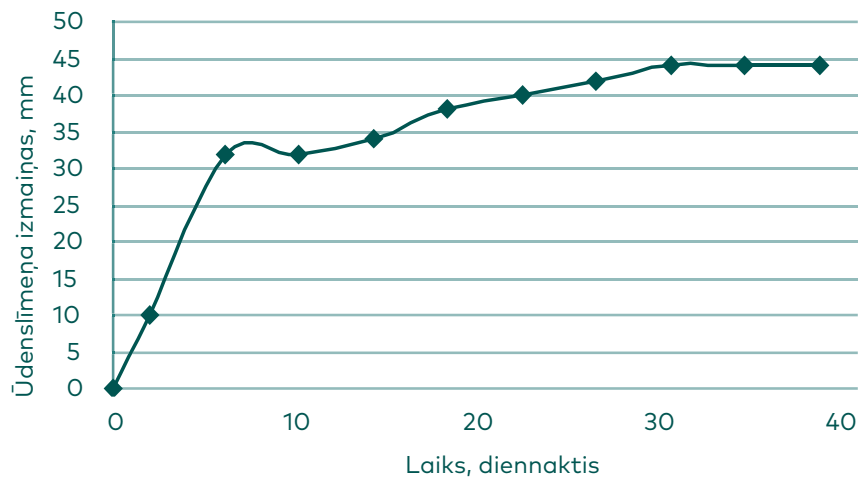

1. att. Caurlaidības noteikšanas iekārtas shēma (a) un Kupravas mālu ūdens caurlaidības mērījumi 40 diennakšu laika periodā (b).

skābekḷa u. c.) piekḷūšanas, kas veicina sadalīšanās produktu izdalīšanos un nokḷūšanu apkārtējā vidē. Viena no būtiskām šādu daudzslāṇu pārklājumu sastāvdaḷām ir māla slānis, kura biezums svārstās caurmērā no 0,3 m līdz 0,6 m. Šādu klājumu veido vietās, kur tiks deponēti atkritumi, lai nepiel̦autu sadalīšanās produktu iekḷūšanu augsnē, kā arī atkritumu izgāztuves virspusē pēc atkritumu vietas aizpildīšanas. Parasti šim nolūkam mēdz izmantot mazāk kvalitatīvus māla slāṇus. Dominējošā īpašība (kā atzīmēts augstāk), kuru šajā gadījumā uzstāda mālam ir tā caurlaidība attiecībā uz lietus ūden,iem. Ir pielietota vienkāršota caurlaidības 
noteikšanas iekārta, kuras shematisks attēlojums dots 1. $a$ att. Ūdens līmeña izmainas, pielietojot Kupravas karjera māla virsējos slānus 40 diennakšu laikā parādītas $1 . b$ att. Redzams, ka jau pēc 40 diennaktīm ūdens līmeña kritums stabilizējas, kas nozīmē to, ka māli ir 'uzbrieduši' un līdz ar to pietiekami noblīvējuši ūdens caurteci. Kopumā šis ūdens līmeña kritums ir niecīgs. Saskañā ar standartā doto aprēksina formulu šo mālu ūdens līmeña izmaiñas dotajam mērījumam ir $1,30 \cdot 10^{-7} \mathrm{~m} \cdot \mathrm{s}^{-1}$, kas atbilst un ir zemākas par norādītajām normām.

\section{B. Mālu pielietojums kaitīgo jonu sorbcijai}

Šim nolūkam izmantoti aktivizēti (dehidratizēti pie $700{ }^{\circ} \mathrm{C}$ ) Kupravas mālu paraugi, kuriem pārbaudīta spēja sorbēt $\mathrm{Cr}^{3+}, \mathrm{Cr}^{6+}, \mathrm{Cu}^{2+}$ un $\mathrm{Zn}^{2+}$ jonus no piesārnnotiem ūdeņiem pēc galvanizācijas procesa. Rezultāti ir parādīti 2. att.

Kā redzams no Kupravas māla paraugu sorbcijas spējas pārbaudēm, izejas šķīdumos ar kaitīgo jonu $\mathrm{Cr}^{3+}, \mathrm{Cu}^{2+}$ un $\mathrm{Zn}^{2+}$ sākotnējo koncentrāciju 1-1,5 mg./l sorbcija ir ievērojama, un šo jonu koncentrācija šķīdumā pēc $24 \mathrm{~h}$ ir samazināta, sasniedzot pat zemāku vērtību par maksimāli piel̦aujamo koncentrāciju $(0,15 \mathrm{mg} / \mathrm{l})$ ūdeņos, kas izveidojušies galvanizācijas procesā. Kā redzams, $\mathrm{Cr}^{6+}$ jona sorbcija nav notikusi. Tas ir saistīts ar tā izmēra nesavietojamību ar mālu mikroslānnu starpplākšnu attālumu, kas ir mazāks par šĩ jona izmēriem.
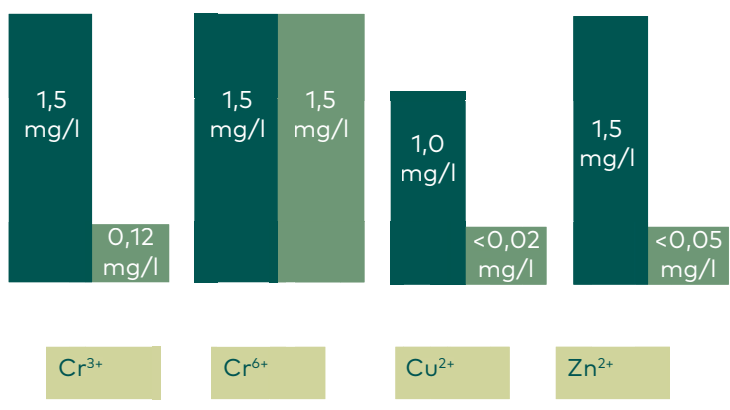

2. att. $\mathrm{Cr}^{3+}, \mathrm{Cr}^{6+}, \mathrm{Cu}^{2+}$ un $\mathrm{Zn}^{2+}$ jonu koncentrācijas izmainas piesārnotos galvaniskos ūdenos pēc $24 \mathrm{~h}$ apstrādes ar dehidratizētiem Kupravas māliem.

\section{Mālu un citu Latvijas minerālo izejvielu pielietojums poru saturošas augsttemperatūras keramikas izstrādei}

Šādas keramikas izstrādei, izmantojot Latvijas minerālās izejvielas (illītu mālus, dolomītu, kvarca smiltis), ir pielietota kompleksa pieeja, izejot no tradicionāli iegūto augsttemperatūras kristālisko savienojumu veidošanās paaugstinātās temperatūrās, kas parādītas fāžu līdzsvara diagrammās. Tradicionāli viena no keramikas materiālu fāžu veidošanās pamatsistēmām ir $\mathrm{MgO}-\mathrm{Al}_{2} \mathrm{O}_{3}-\mathrm{SiO}_{2}$. 3. att. parādīti savienojumi, kas 


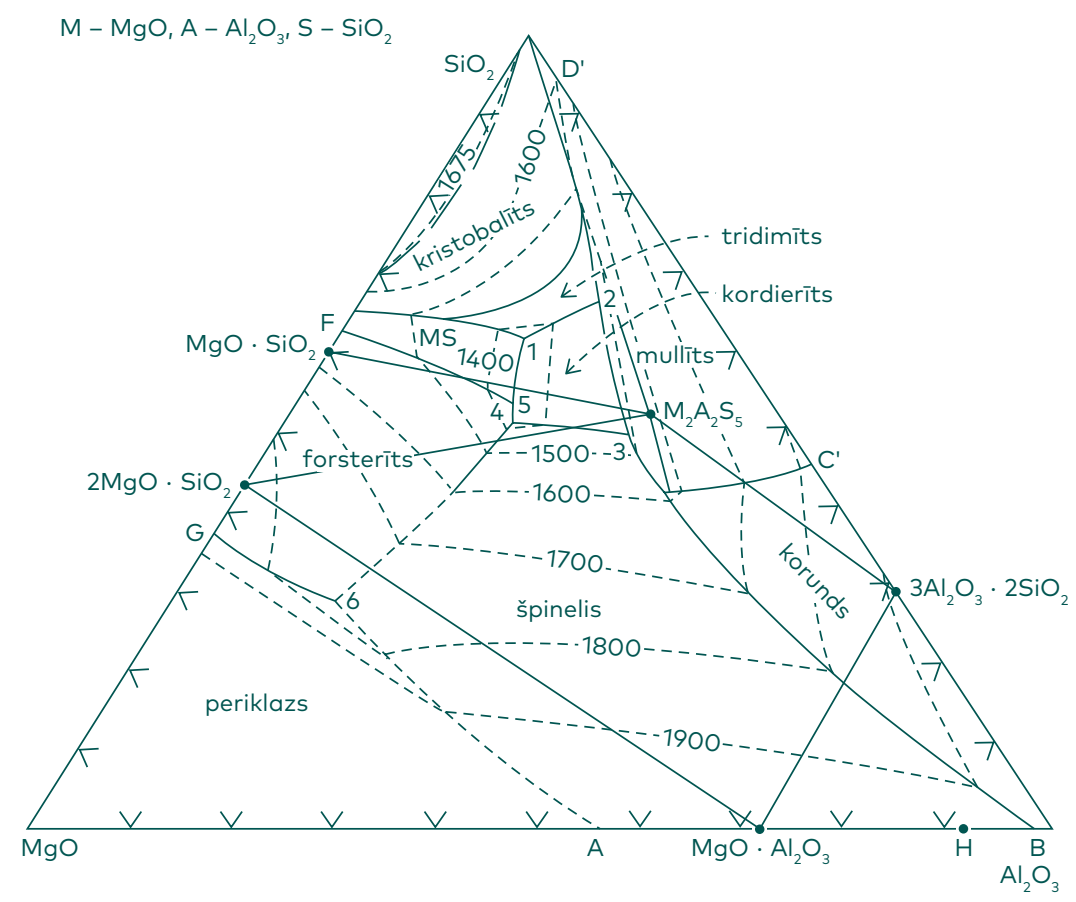

Latvijas minerālās

3. att. Kristālisko fāžu veidošanās sistēmā $\mathrm{MgO}-\mathrm{Al}_{2} \mathrm{O}_{3}-\mathrm{SiO}_{2}$.

veidojas šajā sistēmā no oksīdu maisījuma attiecīgās koncentrācijās un pie attiecīgas apdedzināšanas temperatūras [9].

Kā redzams, dažādu sastāvu augsttemperatūras savienojumu veidoŠanās iespējas sistēmā $\mathrm{MgO}-\mathrm{Al}_{2} \mathrm{O}_{3}-\mathrm{SiO}_{2}$ ir lielas. Šie savienojumi mainās, galvenokārt atkarībā no izejas maisījuma sastāva un apdedzināšanas temperatūras. Var izšk̦irt daudzus iespējamos sastāvus, kas iegūti dažādām pielietoto izejvielu kombinācijām. Viena no dominējošām fāzēm, kurai ir liela praktiska nozīme ir kordierìts. Kordierīta struktūras formula $\mathrm{Mg}_{2} \mathrm{Al}_{3}\left[\mathrm{AlSi}_{5}\right]_{18}$ norāda uz šādu oksīdu masu attiecību: MgO 13,78 masas $\%, \mathrm{Al}_{2} \mathrm{O}_{3}-34,86$ masas $\%, \mathrm{SiO}_{2}-51,36$ masas\%.

$\mathrm{MgO}$ un $\mathrm{Al}_{2} \mathrm{O}_{3}$ saturoši izejvielu maisījumi parasti augstās temperatūrās veido magnija špineli $\mathrm{MgAl}_{2} \mathrm{O}_{4}$, savukārt $\mathrm{MgO}$ un $\mathrm{SiO}_{2}$ maisījumi veido enstatītu $\mathrm{MgSiO}_{3}$ vai forsterītu $\mathrm{Mg}_{2} \mathrm{SiO}_{4}$.

Literatūrā nav sastopami pētījumi par keramikas sintēzi, kuras kristālisko fāzi veidotu kordierīts, špinelis vai enestatīts un kura tiktu iegūta, izmantojot dabas minerālās izejvielas - illītus saturošos mālus un dolomītu maisījumā ar sintētiskām izejvielām, lai atdarinātu šo minēto savienojumu stehiometriju. Problēma, acīmredzot, ir apstāklī, ka dabas minerālo izejvielu klātesamība saķepināšanas procesā veicina ne vien domātās kristāliskās fāzes veidošanos, bet generē arī pietiekama 
Izejvielu maisijumu komponentes (masas daḷas) porainas keramikas ieguvei ar dominējošu špineḷu kristālisko fāzi

\begin{tabular}{llllcc}
\hline \multicolumn{2}{c}{ Sintētiskās izejvielas } & & \multicolumn{2}{c}{ Dabas minerālās izejvielas } \\
\hline $\mathrm{MgO}$ & $\mathrm{K}_{2} \mathrm{CO}_{3}$ & $\gamma-\mathrm{Al}_{2} \mathrm{O}_{3}$ & $\begin{array}{c}\text { Bāles } \\
\text { smiltis }\end{array}$ & $\begin{array}{c}\text { Kranciema } \\
\text { dolomīts }\end{array}$ & $\begin{array}{c}\text { Piezīmes: } \\
\text { izmantoto } \\
\text { mālu } \\
\text { atradnes }\end{array}$ \\
\hline $8,2-9,5, \quad 4,5-6,5$ & $22,6-28,8$ & $31,4-35,7$ & $6,5-8,2$ & $4,5-8,2$ & $\begin{array}{c}\text { Spartaka, } \\
\text { Kalnciema, } \\
\text { Kupravas, } \\
\text { Lažas }\end{array}$ \\
\hline
\end{tabular}

daudzuma gāzveida un šķidrās fāzes, kas šī parauga dzesēšanas procesā nodrošina noteiktu porozitāti saḳepinātajā paraugā. Šis pienēēmums (hipotēze) bija par pamatu poru keramikas izstrādei, pielietojot minerālās izejvielas. Šāda pieeja nodrošina poru un domātās kristāliskās fāzes veidošanos, bet nenodrošina iegūtā poru saturošās keramikas parauga stingri noteikta poru diapazona ieguvi, kā arī atkārtojamību.

Izejas komponenšu daudzumi tika izvēlēti tādās attiecībās, lai nodrošinātu ne vien kristālisko fāžu veidošanos, bet lai arī akcentētu poru veidošanos un iegūtu augsttemperatūras keramisku porainu materiālu (kura kristālisko fāzi veidotu kordierīts, špinelis vai enstatīts). Šo materiālu nodomāts iespējami pielietot gaisa aizsardzībai no izplūdes dūmgāzēm (auto izplūdes gāzes, no dažādu ražošanas procesu dūmi u. c.), kā arī šksidru substanču filtrēšanai/attīrīšanai no piemaisījumiem u. c.

Pētìto paraugu ar prognozētās špineḷu kristāliskās fāzes [10]-[12] veidošanos izejvielu maisījumi parādīti I. tabulā.

Paraugi tika saķepināti $1 \mathrm{~h} 1200-1400^{\circ} \mathrm{C}$ temperatūrās. Vērā nuemami rezultāti tika novēroti, sākot ar saksepināšanu $1300{ }^{\circ} \mathrm{C}$ un $1350{ }^{\circ} \mathrm{C}$

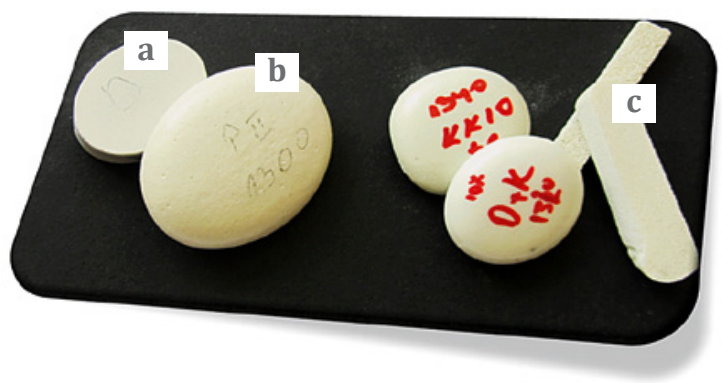

4. att. Poras saturošu $1300{ }^{\circ} \mathrm{C}$ temperatūrā saķepinātu keramikas paraugu vizualizācija: neapdedzināts paraugs (a), apdedzināts paraugs (b) un tā šķēlums (c). 
temperatūrās. Kā redzams 4. att., paraugu izmēri pieaug un ir novērojama poru veidošanās.

Pielietojot šādu poru keramikas saḳepināšanas tehnologiju, veidojas makroporainība ar poru izmēriem $\leq 1 \mathrm{~mm}$, kā redzams 5 . att. un 6. att. Tomēr gan poru izmēri, gan arī poru kopējais tilpums nav stingri kontrolējams, kā tas varētu būt, ja poras tiktu veidotas parauga formēšanas procesā.

Kā redzams 5. att. un 6. att., keramikas materiāla paraugi ar Kupravas māla piedevu izejas maisījumos raksturojami ar porainu drumstalu un vizuāli saskatāmām makroporām (līdzīgs poru diferenciālais sadalījums ir arī paraugos ar Lažas mālu piedevām). Dominējošās ir divu veidu

a
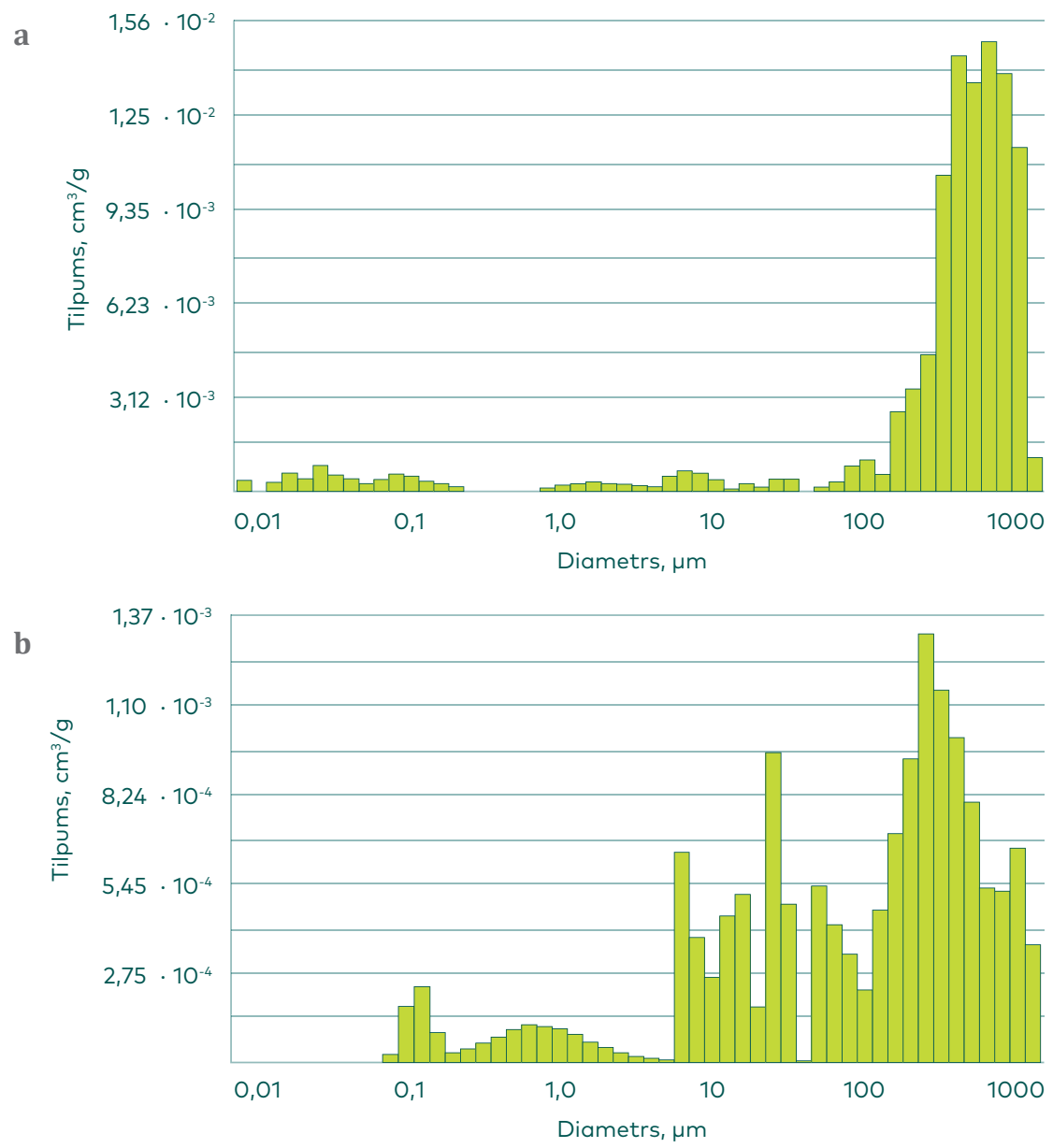

5. att. Poru diferenciālais sadalījums paraugā (Kupravas māla piedeva 10 masas\%), kas saķepināts $1320^{\circ} \mathrm{C}$ (a) un $1340^{\circ} \mathrm{C}$ temperatūrā (b). 
a

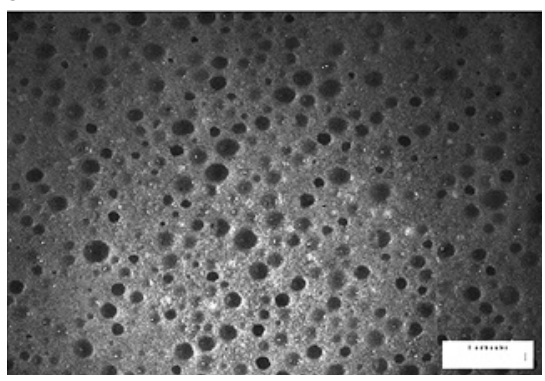

b

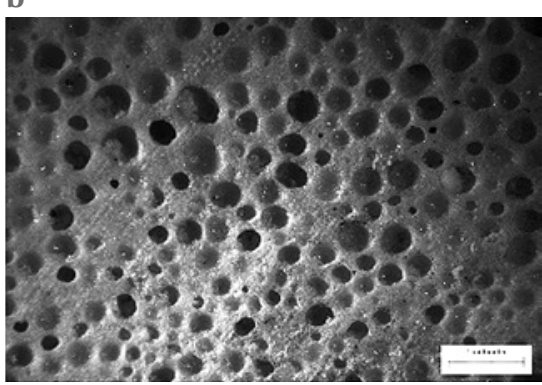

6. att. Porainas keramikas parauga, kas sakepināts $1320^{\circ} \mathrm{C}$, optiskā mikroskopa fotogrāfija (a), kā arī tas pats pie $1340^{\circ} \mathrm{C}$ (b).

poras - mezoporas (no 0,1 $\mu \mathrm{m}$ līdz $10 \mu \mathrm{m}$ ) un makroporas (no $10 \mu \mathrm{m}$ līdz $1000 \mu \mathrm{m})$.

Kā rāda rentgenogrāfiskie pētījumi šādas porainā keramikā dominējošā kristāliskā fāze ir augsttemperatūras savienojums - magnija špinelis $\mathrm{MgAl}_{2} \mathrm{O}_{4}$, savukārt pavadošās fāzes ir kvarcs $\mathrm{SiO}_{2}$ un anortīts $\mathrm{Ca}\left[\mathrm{AlSiO}_{4}\right]_{2}$, 7. att.

Saķepināšanas temperatūras paaugstināšana paraugam KK10 no $1320{ }^{\circ} \mathrm{C}$ uz $1340{ }^{\circ} \mathrm{C}$ (skat. 7. att.) veicina kristālisko fāžu daudzuma samazināšanos, saglabājoties dominējošai magnija špineḷa fāzei. Kristāliskā fāze anortīts pie $1340{ }^{\circ} \mathrm{C}$ ir sadalījusies, veidojot stiklveida fāzi, uz ko norāda pie atstarošanas leṇk, $2 \theta \sim 25-30^{\circ}$ izveidojies 'amorfais' izliekums. Savukārt šīs izmaiṇas veicina poru tilpuma palielināšanos, kā arī poru izmēru nelielu izmaiṇu mazāko poru virzienā. To parāda poru diferenciālais sadalījums, skat. 5. att. un 6. att. Ir arī konstatēts, ka paraugos

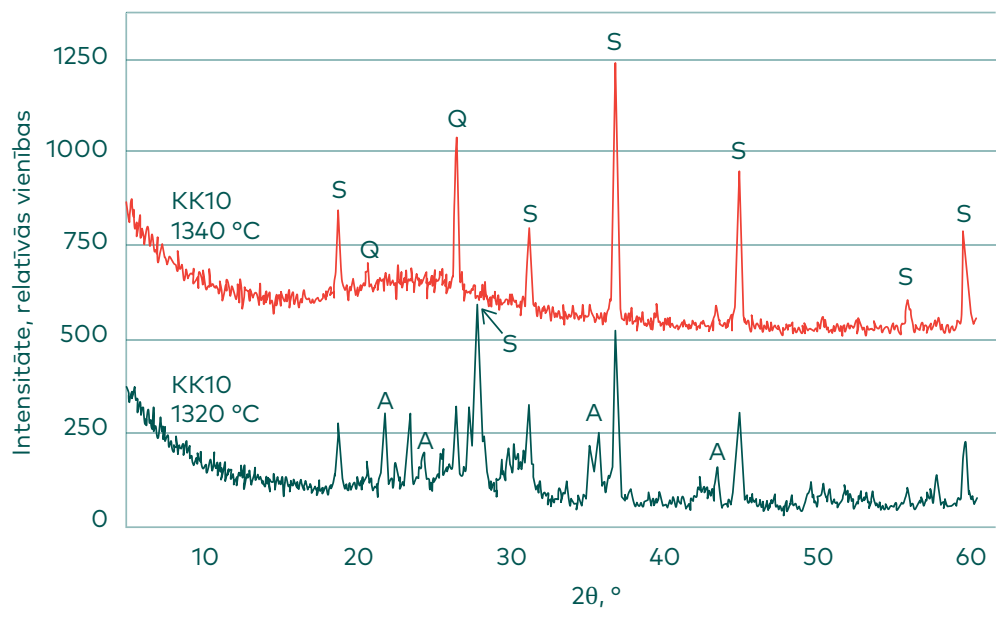

$\mathrm{S}$ - magnija špinelis $\mathrm{MgAl}_{2} \mathrm{O}_{4}$ $\mathrm{Q}-$ kvarcs $\mathrm{SiO}_{2}$ A - anortīts $\mathrm{Ca}\left[\mathrm{AlSiO}_{4}\right]_{2}$

7. att. Rentgenogrammas porainas keramikas paraugiem ar Kupravas māla piedevu $10 \%$, kas saksepināti $1320^{\circ} \mathrm{C}$ un $1340^{\circ} \mathrm{C}$ temperatūrās. 
ar Lažas māla piedevu nav būtisku atšķirību kristālisko fāžu sastāvā, salīdzinot ar Kupravas māla piedevu.

Būtiski ir atzīmēt, ka augstāk minētie rezultāti iegūti, pielietojot četru atradṇu mālus kā piedevas (Spartaka/Ānes, Kalnciema, Kupravas un Lažas atradnes), saglabājot nemainīgu pārējo sastāvdaḷu masu attiecību. Šāda pieeja ḷāva iegūt secinājumus par katra pielietotā māla ietekmi uz poru veidošanos keramikas paraugos. Varētu domāt, ka saistībā ar poru veidošanos mālu (ar dažādu ķīmisko un mineraloǵisko sastāvu) atradṇu izvēlei ir nozīme. Konstatēts, ka stiklveida fāzes un līdz ar to arī poru veidošanos ievērojami ietekmē Kupravas māls, mazākā mērā - Lažas māls. Ānes atradnes māli neveicina poru veidošanos. Korelējot šos rezultātus ar mālu ḳ̄misko sastāvu, var secināt, ka liela nozīme ir dzelzs oksīda saturam sastāvā, kā arī katra atsevišķa oksīda daudzumam. Šie oksīdi var veidot eitektisku maisījumu, veicinot tādas viskozitātes šķidrās fāzes veidošanos, kas dzesēěanas procesā var 'iekapsulēt' izveidojušās poras. No šì viedokḷa par seviškşi optimālām ir atzīmējamas Kupravas un Lažas atradṇu mālu piedevas.

Poras saturoša keramika ar kordierīta $\left(\mathrm{Mg}_{2} \mathrm{Al}_{4} \mathrm{Si}_{5} \mathrm{O}_{18}\right)$ kristālisko fāzi raksturojama kā termisku triecienu izturīga keramika, kurai vienlaicīgi piemìt arī laba spiedes izturība, relatīvi zemi siltumvadāmības un sevišķi lineārās termiskās izplešanās $\left(1,5 \cdot 10^{-6}-4,0 \cdot 10^{-6} \mathrm{~K}^{-1}\right)$ koeficienti. Šì materiāla īpašības nodrošina tā struktūra, kurā dominējošā kristāliskā fāze ir augsttemperatūras $\alpha$-kordierīts, kas ir veidots no 6-locekḷu $\left[\mathrm{SiO}_{4}\right]^{-}$gredzeniem un $\left[\mathrm{AlO}_{4}\right]^{-}$tetraedriem, kas saistīti ar $\left[\mathrm{AlO}_{6}\right]^{-}$oktaedriem un, negatīvo lādiṇu kompensācijai realizējoties ar $\mathrm{Mg}^{2+}$ joniem, kas izvietoti starp šiem daudzskaldṇiem. Struktūras shematisks attēlojums ir parādīts 8. att., kuram blakus novietots kordierīta šūnveida materiāls auto izplūdes gāzu attīî̌šanai/izvadīšanai. Šādu materiālu, kā arī cita veida filtrējošu un arī katalizatoru augsttemperatūras materiālu izstrādi nodrošina kordierīta struktūra. Savukārt blīvu kordierīta materiālu, kam
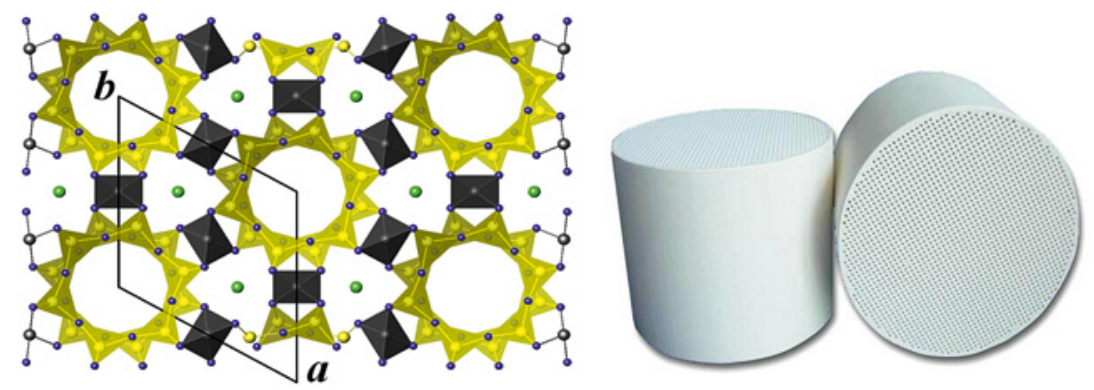

8. att. Kordierīta struktūras shematiska attēlojums [14] un šūnveida kordierīta materiāls auto izplūdes gāzu attīrīšanai. 
piemìt zema dielektriskā konstante $(\varepsilon \approx 4)$ un zema elektrovadītspēja (pretestība $\rho>10^{12} \Omega \cdot \mathrm{cm}$ ), pielieto kā izcilu dielektriksi mikroelektronikā.

Dabā šis minerāls ir reti sastopams, to parasti iegūst sintētiskā ceḷā, saķepinot izejvielu maisījumu paaugstinātās temperatūrās cietvielu reakciju rezultātā, vai arī iegūstot no attiecīga stiklveida kausējuma tā kristalizācijas rezultātā, vai sola-gela procesā, piemēram, [15], [16]. Pielietojot sintētiskās izejvielas, var plaši variēt kordierīta îpašības un līdz ar to arī pielietošanas iespējas. Ne mazāk svarīgs faktors ir arī tā ieguves izmaksu samazinājums, it sevišķi tas attiecas uz saksepināšanas temperatūras samazinājumu. Tradicionāli kordierīts tiek sintezēts (saksepināts) aptuveni $1350-1400{ }^{\circ} \mathrm{C}$ temperatūrā un veidojas cietvielu reakciju rezultātā. Tā saķepināšanas temperatūras pazemināšanai oksīdi tiek aizstāti ar attiecīgiem sāljiem, hidroksīdiem u. c. (piemēram, $\mathrm{MgCO}_{3}, \mathrm{Al}(\mathrm{OH})_{3}$ ) vai arī dabas materiāliem, piemēram, talku, mālu minerāliem (kaolinītu, sepiolītu, vermikulītu u. c.), ražošanas atlikumiem un citām šķidrās fāzes veidošanos veicinošām piedevām saḳepināšanas procesā $\left(\mathrm{B}_{2} \mathrm{O}_{3}\right.$, $\mathrm{P}_{2} \mathrm{O}_{5}, \mathrm{Ca}^{2+}, \mathrm{Na}^{+}, \mathrm{K}^{+}, \mathrm{Fe}(\mathrm{II})$ un $\mathrm{Fe}(\mathrm{III})$ savienojumiem u. c.).

Nav zināmi sistemātiski pētījumi par illītu saturošu mālu izmantošanu kordierīta sintēzei. Parasti illīta māli tiek pievienoti ap $35 \%$ daudzumā tradicionālai akmens masas keramikai, kas tiek iegūta no laukšpata, smiltīm un grūti kūstošiem māliem [20]. Bet nav zināmi gadījumi, kad šie māli, kā arī dolomìts un kvarca smiltis ir izmantoti kopā ar sintētiskiem savienojumiem augsttemperatūras keramikas (kordierīta, špinel̦a vai enstatīta) izstrādē. To kopējais pievienotais daudzums nedrīkstētu pārsniegt 50-55 \%. Pretējā gadījumā keramikas materiālā pieaug amorfās fāzes daudzums, kas samazina keramikas mehāniskās un termiskās īpašības. Dotajā pētījumā ir parādīta kordierīta fāzi saturošas porainas keramikas izstrāde, pielietojot Latvijas minerālās izejvielas - vairāku atradṇu illìtu mālus, kā arī kvarca smiltis, dolomītu un ķīmiskos savienojumus, lai nodrošinātu kordierīta veidošanos.

Poras saturoša kordierīta keramikas izejvielu maisījumu sastāvā ir $50 \%$ minerālo izejvielu (illītu māli, kvarca smiltis, dolomīts) un $50 \%$ sintētisko izejvielu ( $\left.\mathrm{MgO}, \gamma-\mathrm{Al}_{2} \mathrm{O}_{3}, \mathrm{~K}_{2} \mathrm{CO}_{3}\right)$. To procentuālās attiecības dotas II. tabulā, bet 9 . att. shematiski ir parādīta reakciju secība, kas notiek (vai arī var notikt) šādā maisījumā paaugstinātā temperatūrā [5] līdz maksimālai temperatūrai $1300^{\circ} \mathrm{C}$.

Kordierīta fāzes attīstību atkarībā no temperatūras un, ngemot vērā kristālisko fāžu veidošanās secību un izejot no to simetrijas lieluma, var aprakstīt sekojošu shematisku reakciju veidā (piemēram, sastāvam II, 3. tabula). Pēc illīta sadalīšanās aptuveni $700{ }^{\circ} \mathrm{C}$ temperatūrā un dolomìta sadalīšanās $800-900^{\circ} \mathrm{C}$ temperatūrā veidojas šķidrā fāze un notiek jonu difūzijas process, veidojot jaunus savienojumus, kuru veidošanās secību var aprakstīt sekojoši: 


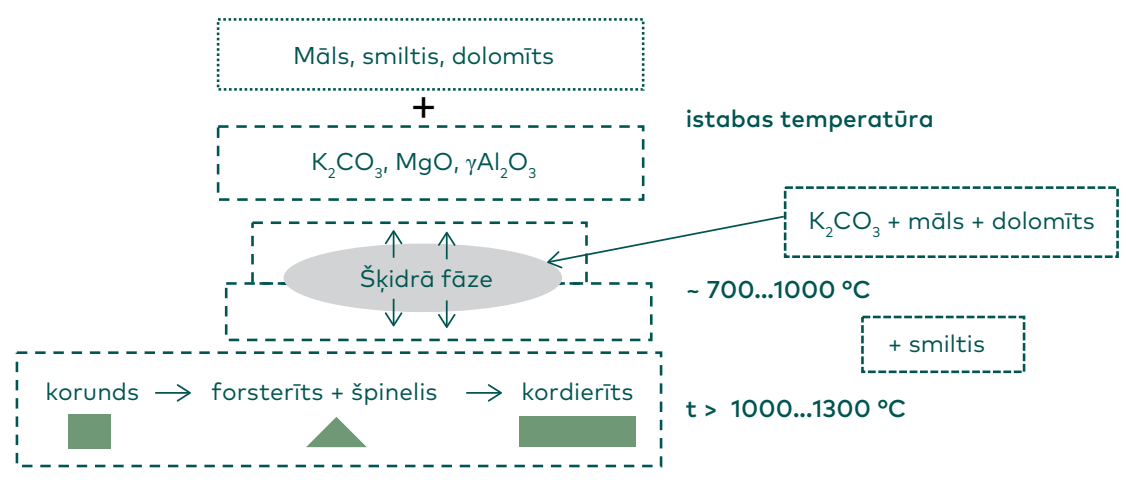

Latvijas minerālās

izejvielas

eko-keramikas

9. att. Augsttemperatūras fāžu veidošanās secība keramikā no jaukta sintētisko izejvielu (aptuveni 50 masas\%) un minerālo izejvielu maisījuma.

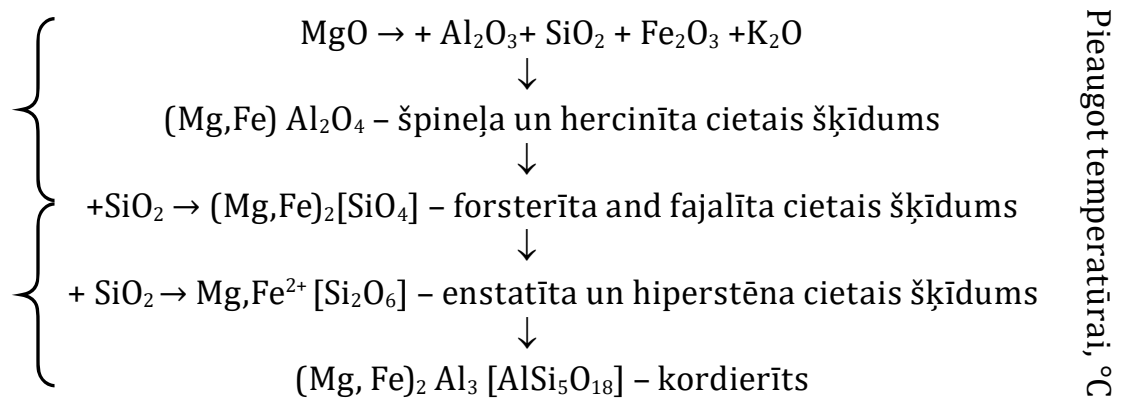

Savukārt paralēli notiek arī gāzveida fāzes veidošanās, notiekot zemāk shematiski parādītajām reakcijām. $750-900{ }^{\circ} \mathrm{C}$ temperatūrā vienlaicīgi sāk sadalīties karbonātus saturošie minerāli:

- $\mathrm{CaCO}_{3} \cdot \mathrm{MgCO}_{3} \rightarrow \mathrm{CaO}+\mathrm{MgO}+2 \mathrm{CO}_{2} \uparrow ;$

- $\mathrm{Fe}^{3+}$ reducējas par $\mathrm{Fe}^{2+}$.

Praktiskos pētījumos ir veidotas dažādu sastāvu kompozīcijas. Piemēram, II. tabulā ir parādīti izejas maisījumu sastāvi blīvas kordierīta

II. tabula

Izejas maisījumu kompozīcijas blīvas kordierīta keramikas izstrādei, masas\%

\begin{tabular}{|c|c|c|c|c|c|c|}
\hline \multirow[b]{2}{*}{ Paraugs } & \multirow[b]{2}{*}{$\mathrm{MgO}$} & \multirow[b]{2}{*}{$\mathrm{K}_{2} \mathrm{CO}_{3}$} & \multirow[b]{2}{*}{$\gamma \mathrm{Al}_{2} \mathrm{O}_{3}$} & \multicolumn{3}{|c|}{ Minerālās izejvielas } \\
\hline & & & & $\begin{array}{l}\text { Kvarca } \\
\text { smiltis }\end{array}$ & Dolomīts & $\begin{array}{l}\text { Illītu māls } \\
\text { (B) }\end{array}$ \\
\hline 0 & $12,0-12,5$ & $7,1-7,5$ & $33,5-34,0$ & $46,0-47,0$ & - & - \\
\hline 1 & $11,5-12,3$ & $6,5-7,0$ & $30,5-31,8$ & $42,0-43,0$ & 4,5 & 4,5 \\
\hline II & $10,3-11,2$ & $5,8-6,2$ & $27,2-28,5$ & $39,0-40,5$ & 8,2 & 8,2 \\
\hline III & $8,5-9,0$ & $5,1-5,8$ & $24,1-24,8$ & $33,5-34,7$ & 14,0 & 14,0 \\
\hline
\end{tabular}


$2018 / 35$

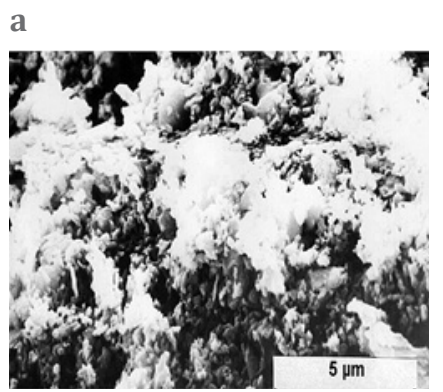

b

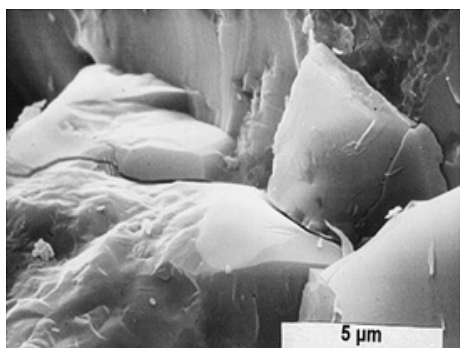

c

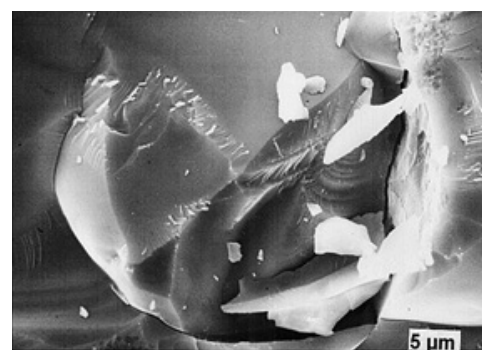

10. att. Skenējošãs elektronu mikroskopijas attēli: kordierīta kristāliskās fāzes veidošanās sastāvam I atkarībā no saḳepināšanas temperatūras:

$\mathrm{a}-1100{ }^{\circ} \mathrm{C}, \mathrm{b}-1200^{\circ} \mathrm{C}, \mathrm{c}-1300^{\circ} \mathrm{C}$.

keramikas iegūšanai, bet III. tabulā ir parādīti sastāvi poras saturošas kordierīta keramikas izstrādei. Kā redzams, porainas keramikas izejas maisījumos ir ievērojami palielināts mālu daudzums, savukārt samazināts kvarca smilšu daudzums, ievadot $\mathrm{MgCO}_{3}$ un $\mathrm{Al}(\mathrm{OH})_{3}$ kā aktīvas kordierīta stehiometriju veidojošas komponentes (III. tabula). Šīs izmaiṇas vērstas uz hipotēzi par šksidrās fāzes veidošanās veicināšanu, kuras

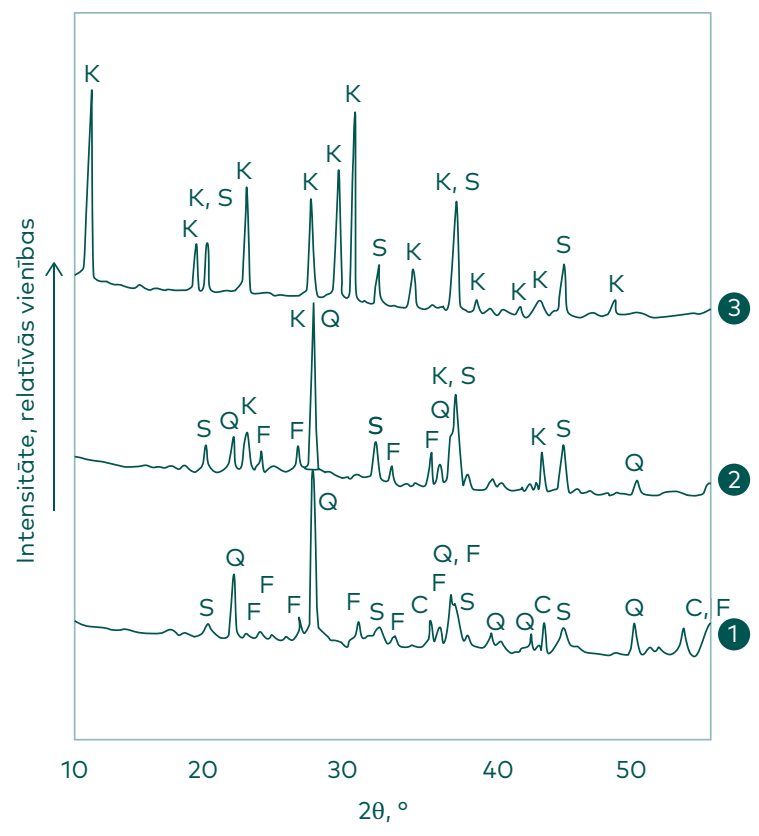

$\mathrm{K}$ - kordierīts $\left(\mathrm{Mg}, \mathrm{Fe}^{2+} \mathrm{Al}_{3}\right)_{2}\left[\mathrm{AlSi}_{5} \mathrm{O}_{18}\right]$

$\mathrm{S}$ - špinelis $\mathrm{MgFe}_{2} \mathrm{O}_{4}$

$\mathrm{F}$ - forsterīts $\left(\mathrm{Mg}_{1}, \mathrm{Fe}_{2}\right)_{2}\left[\mathrm{SiO}_{4}\right]$

$Q-$ kvarcs $\mathrm{SiO}_{2}$

$\mathrm{A}$ - korunds $\mathrm{a}-\mathrm{Al}_{2} \mathrm{O}_{3}$

11. att. Pulvera maisījuma I rentgenogrammas dažādās temperatūrās saksepinātiem paraugiem: $1-1100{ }^{\circ} \mathrm{C}, 2-1200{ }^{\circ} \mathrm{C}, 3-1300^{\circ} \mathrm{C}$. 
viskozitāte nodrošinātu izveidojošos poru 'iekapsulēšanu' keramiskajā matricā dzesēšanas procesā.

Kordierīta kristāliskās fāzes morfologiijas veidošanās šajā keramikā pie dažādām sakepepināšanas temperatūrām parādīta 10. att.

Šie skenējošās elektronu mikroskopijas (SEM) attēli liecina, ka sastāva I, kas saḳepināts $1100^{\circ} \mathrm{C}$ temperatūrā, struktūrā dominē kristāliskā fāze ar vāji izteiktām kristālu formām (10. $a$ att.). Pieaugot apdedzināšanas temperatūrai līdz $1200{ }^{\circ} \mathrm{C}$ un sevišşki līdz $1300^{\circ} \mathrm{C}(10 . b$ att. un 10. $c$ att.), ir redzami labi izveidojušies balti pelēcīgi idiomorfi kordierīta kristāli ar vāju skaldnību pa prizmas plakni (010) un gliemežveidīgu lūzumu paraugam, kas apdedzināts $1300{ }^{\circ} \mathrm{C}$ temperatūrā. Šādu idiomorfu prizmatisku kristālu veidošanās ir saistāma ar to, ka kordierīta anjonu dalı u veido sešlocekḷ gredzens $\left[\mathrm{AlSi}_{6} \mathrm{O}_{18}\right]^{-13}$, kas orientēts perpendikulāri $c$ kristaloḳimiskajam virzienam. Šos sešlocekḷu gredzenus savā starpā saista $\mathrm{Mg}^{2+}, \mathrm{Fe}^{2+}$ un $\mathrm{Al}^{3+}$ joni [14].

Kā redzams no rentgenstaru difraktogramām (11. att.), kordierīts veidojas no pulvera maisījuma I temperatūrās sākot no $1200^{\circ} \mathrm{C}$, reaǵējot kvarcam un forsterītam. Temperatūru intervālā no $1200{ }^{\circ} \mathrm{C}$ līdz $1300{ }^{\circ} \mathrm{C}$ iespējama arī starpfāžu (enstatīta un hiperstēna cieto šķīdumu) veidošanās, kuras rentgenogrāfiski nav konstatētas. $1300^{\circ} \mathrm{C}$ temperatūrā ir izveidojies keramisks materiāls, kura dominējošā kristāliskā fāze ir kordierīts.

Raksturīgākā kordierīta keramikas īpašība ir tās zemais lineārās termiskās izplešanās koeficients $2 \cdot 10^{-6}-4 \cdot 10^{-6} \mathrm{~K}^{-1}$, kas nodrošina augstu termiskā trieciena izturību. Termiskā trieciena izturība šajā darbā ir noteikta kā elastības moduḷa (Junga moduḷa) piel̦aujamā samazināšanās pēc straujiem parauga uzkarsēšanas-atdzesēšanas cikliem. Tā piel̦aujama ne vairāk par $30 \%$ [18]. Šie rādītāji ir noteikti pēc, piemēram, kordierīta keramikas parauga I pakḷaušanas straujas uzkarsēšanas un atdzesēšanas režīmam 10 ciklus ar elastības moduḷa mērījumu un novērtējumu pēc katra cikla.

Dotajam paraugam šĩs vērtības iekḷaujas piel̦aujamās robežās [18], kā tas ir parādìts 12. att.

III. tabula Izejas maisījumu kompozīcijas poru kordierīta keramikas izstrādei, masas\%

\begin{tabular}{cccccc}
\hline Paraugs & $\begin{array}{c}\text { Pielietoti māli no } \\
\text { atradnes }\end{array}$ & Māli & $\begin{array}{c}\text { Kvarca } \\
\text { smiltis } \\
\text { (Bāle) }\end{array}$ & $\mathrm{MgCO}_{3}$ & $\mathrm{Al}(\mathrm{OH})_{3}$ \\
\hline A5 & Apriki & 33,6 & 22,5 & 16,0 & 27,2 \\
N5 & Nīcgale & 33,2 & 24,2 & 17,0 & 26,2 \\
N2 & Nīcgale & 18,7 & 32,0 & 18,9 & 30,3 \\
\hline
\end{tabular}




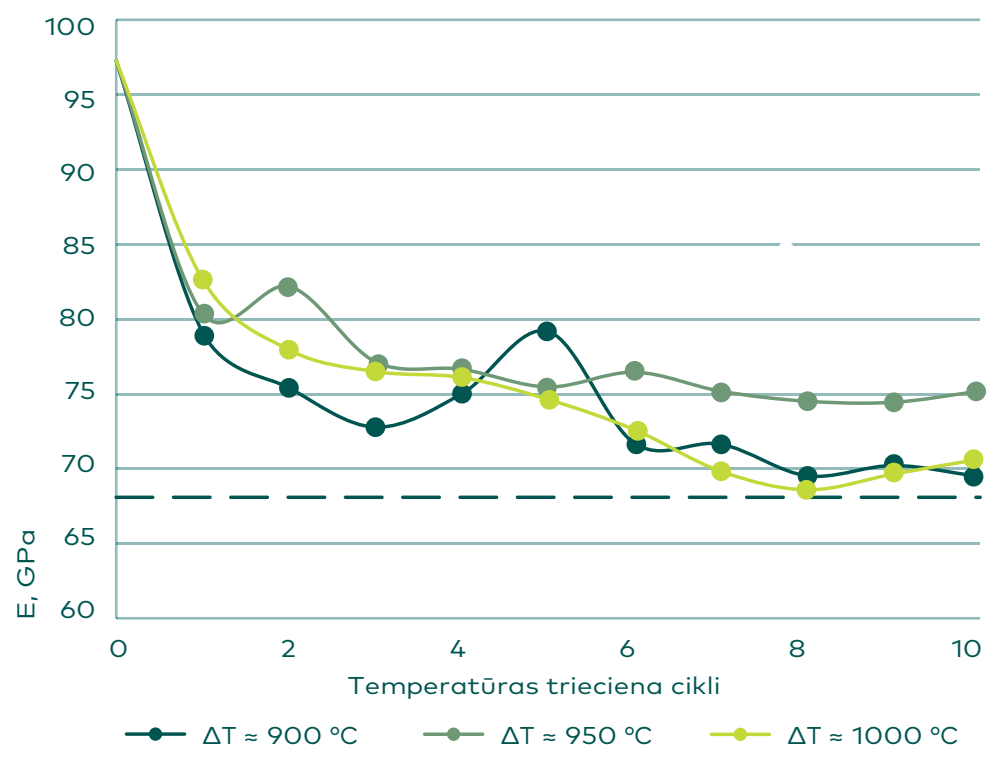

12. att. Elastības moduḷa izmaiṇas paraugam I pēc 10 uzkarsēšanas-dzesēšanas cikliem.

Kā augstāk atzīmēts, lai veidotos gāzveida fāze (poras), sastāvos galvenokārt izmainīta mālu un kvarca smilšu attiecība, pieaugot mālu saturam izejas maisījumos un vienlaicīgi ievadot maisījumā arī $\mathrm{MgCO}_{3}$ un $\mathrm{Al}(\mathrm{OH})_{3}$, lai nodrošinātu kordierīta veidošanās stehiometriju gala produktā. Kā rāda rentgenogrāfiskā fāžu analīze (13. att.) kordierīta fāze ir labi izveidojusies jau $1250{ }^{\circ} \mathrm{C}$ temperatūrā, un tās daudzums būtībā nemainās temperatūrai pieaugot līdz $1350{ }^{\circ} \mathrm{C}$. Kā pavadošā fāze šajos sastāvos ir izveidojusies arī otra augsttemperatūras fāze - špinelis $\mathrm{MgAl}_{2} \mathrm{O}_{4}$. Vizuāli šajos paraugos var novērot arī stiklveida fāzes klātbūtni.

Paraugu fotoattēli ir redzami 14. att. Paraugiem tumšo toni dod Fe jonu klātiene illīta mālos, un vizuāli redzama arī poru klātbūtne.

SEM attēli (15. att.) savukārt parāda, ka poras ir dažu simtu mikronu lielas un ka iegūtie paraugi no porainības viedokḷa ir makroporaini keramikas materiāli un var kalpot kā augsttemperatūras filtri, iespējams arī kā augsttemperatūras izolācijas materiāli. Paraugu atvērtā porainība ir 30-60 \%. Tas gan faktiski neraksturo materiāla filtrēšanas spēju - šajā aspektā būtisks ir caurejošo poru tilpums.

15. att. ir parādīti divi $1250{ }^{\circ} \mathrm{C}$ temperatūrā saķepināti paraugi N5 un A5, kas iegūti no maisījumiem, kuros kā poru veidotāji izmantoti Nīcgales (paraugi N5) un Apriķu (paraugi A5) atradņu māli. Ir redzams, ka poru izmēri/morfologija atšķiras. Keramikas paraugam, kas iegūts no 


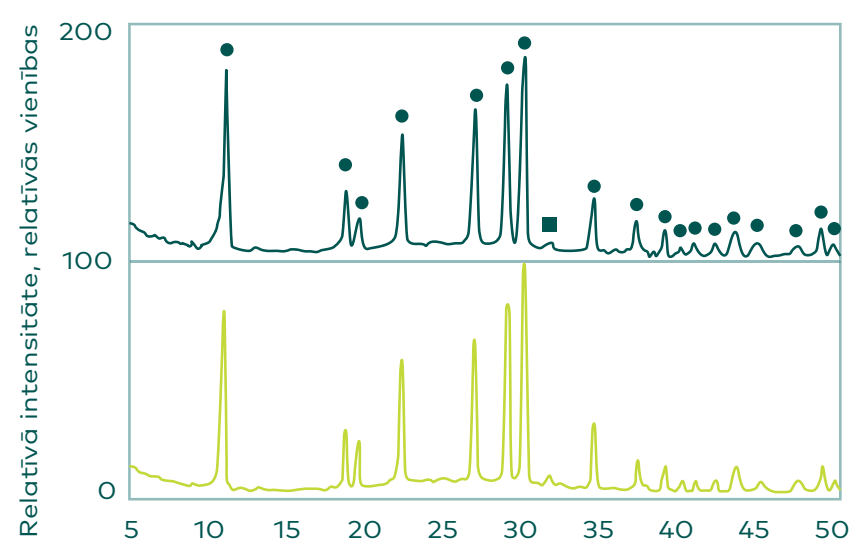

Latvijas minerālās izejvielas eko-keramikas izstrādei
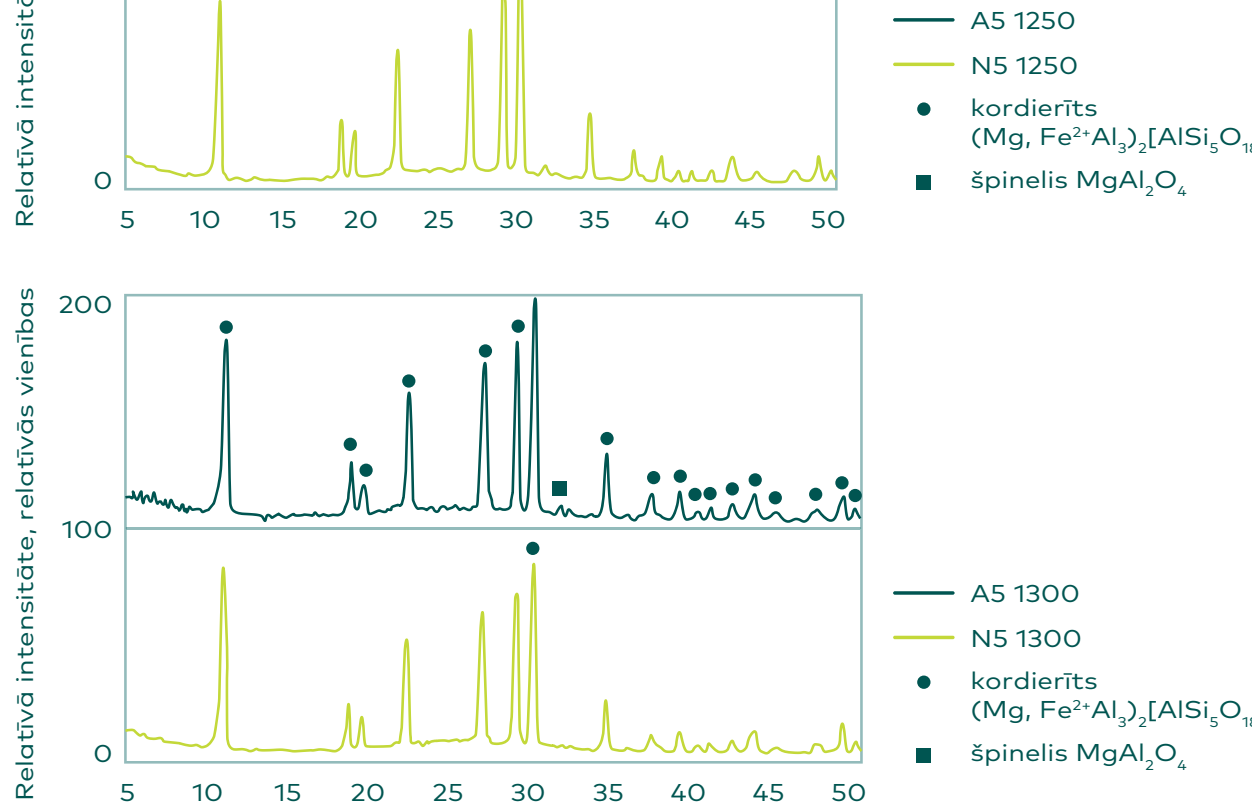

- kordierīts $\left(\mathrm{Mg}, \mathrm{Fe}^{2+} \mathrm{Al}_{3}\right)_{2} \mathrm{CAISi}_{5} \mathrm{O}_{1 \xi}$

- špinelis $\mathrm{MgAl}_{2} \mathrm{O}_{4}$

13. att. Paraugu A5 un N5, kas saksepināti $1250^{\circ} \mathrm{C}$ un $1300^{\circ} \mathrm{C}$ temperatūrās, rentgenogrammas.

a

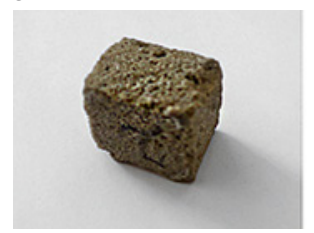

b

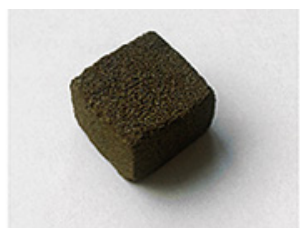

c

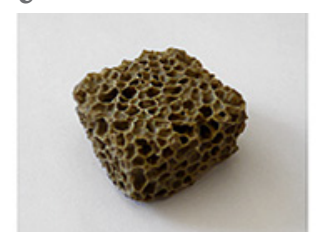

d

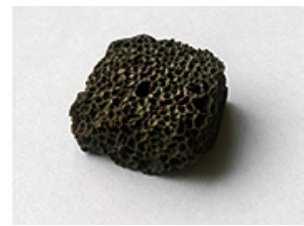

14. att. Paraugu N5 (a un c) un A5 (b un d) fotogrāfijas. Paraugi saksepināti $1250{ }^{\circ} \mathrm{C}$ (a un b) un $1300^{\circ} \mathrm{C}$ (c un d) temperatūrās.

maisījuma ar Nīcgales atradnes mālu, poras ir sīkākas, ar vidējo izmēru ap $240 \mu \mathrm{m}$, un ir relatīvi vienmērīgi sadalītas. Savukārt Apriksu māla klātienē ir izveidojušās lielāka izmēra poras, kuras ir aptuveni divas reizes lielākas. Poru sferolītu forma labāk ir veidota paraugam A5, poru 


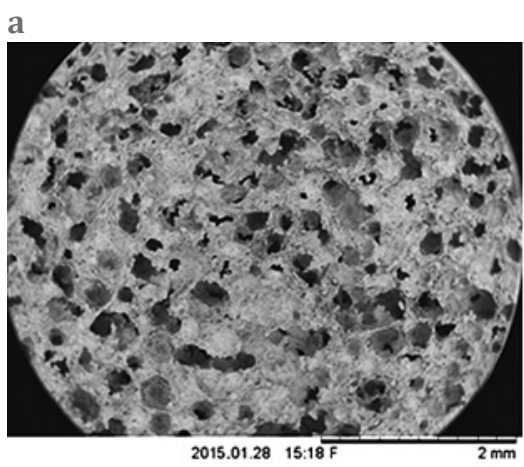

c

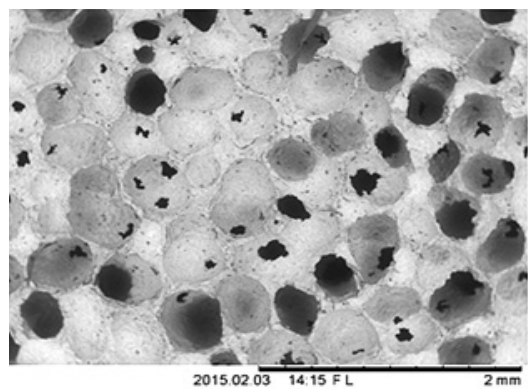

b

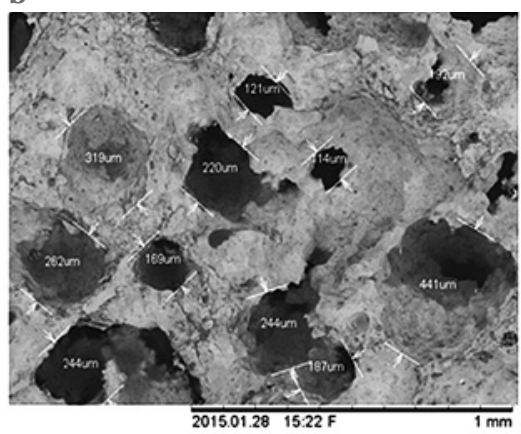

d

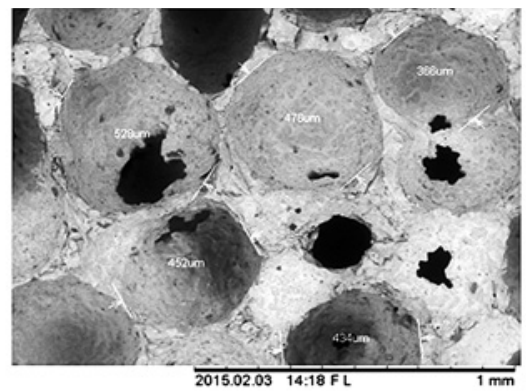

15. att. $1250^{\circ} \mathrm{C}$ temperatūrā saḳepinātu paraugu N5 (a, b) un A5 (c, d) SEM attēli.

sieninas ir cieši savietotas. Parauga N5 poru forma ir neizteikti elipsoìdveida vai arī neregulāra. Lielāki vai mazāki atvērumi/tukšumi norāda uz caurejošo poru klātesamību. Tas ḷauj izdarìt secinājumus par iespēju šo poraino keramiku pielietot kā filtrēšanas materiālu, tajā skaitā pie paaugstinātām $\left(\leq 600^{\circ} \mathrm{C}\right)$ temperatūrām.

IV. tabulā ir dotas dažas poru keramikas īpašības, tai skaitā ir redzams, ka paaugstinot saķepināšanas temperatūru tikai par 50 grādiem un

IV. tabula

Poras saturošu keramikas paraugu raksturīgās īpašības

\begin{tabular}{cccc}
\hline $\begin{array}{c}\text { Paraugs un tā maksimālā } \\
\text { saḳepināšanas temperatūra, }\end{array}{ }^{\circ} \mathbf{C}$ & $\begin{array}{c}\text { Škietamais blīvums, } \\
\mathbf{g} / \mathbf{c m}^{3}\end{array}$ & $\begin{array}{c}\text { Vaḷējā porainība, } \\
\%\end{array}$ & $\begin{array}{c}\text { Spiedes } \\
\text { izturība, MPa }\end{array}$ \\
\hline N5, 1250 & 1,46 & 29,17 & 20,52 \\
A5, 1250 & 1,25 & 39,03 & 16,48 \\
N5, 1300 & 1,02 & 58,80 & $<5,0^{*}$ \\
A5, 1300 & 0,92 & 63,91 & $<5,0^{*}$ \\
\hline
\end{tabular}

* - lielumu nevar noteikt. 


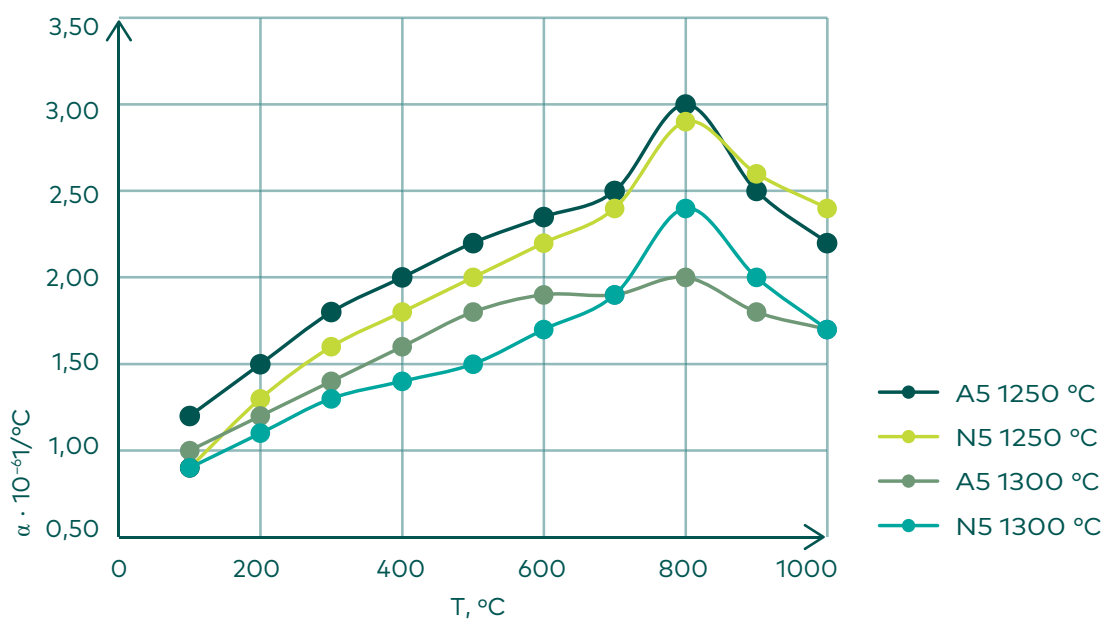

16. att. Poras saturošas kordierīta keramikas paraugu lineārā termiskā izplešanās koeficienta izmaiṇas atkarībā no temperatūras.

pieaugot poru kopējam tilpumam, arī paraugu šķietamais blīvums samazinās, vienlaicīgi samazinoties arī spiedes izturībai (IV. tabula).

Kopā ar porainības un poru izmēru palielināšanos, paaugstinot saķepināšanas temperatūru, likumsakarīgi samazinās cietās fāzes un gāzveida (poru) fāzes attiecība. Tādēl arī redzams, ka šķietamais blīvums ievērojami samazinās (V. tabula). Tas tuvina šo materiālu augsti porainiem 'viegliem' materiāliem, kam piemīt zema izturība $(<5 \mathrm{MPa})$, kas ierobežo to pielietojumu. Pazeminot saķepināšanas temperatūru līdz $1250{ }^{\circ} \mathrm{C}$, šĩs poru keramikas spiedes izturība ievērojami pieaug līdz pat aptuveni $20 \mathrm{MPa}$, vienlaicīgi palielinoties arī tās škietamajam bīvumam. Šìs īpašības varētu nodrošināt keramikas plašu pielietojuu.

Lineārā termiskā izplešanās koeficienta (LTIK) vērtības šiem keramikas paraugiem ir zemas (16. att.). Pieaugot temperatūrai, kā arī atkarībā no izmantotā māla LTIK vērtības ievērojami izmainās. Izveidojoties amorfai/škidrai $\mathrm{CaO}-\mathrm{K}_{2} \mathrm{O}-\mathrm{SiO}_{2}$ saturošai fāzei aptuveni $800{ }^{\circ} \mathrm{C}$ temperatūrā LTIK vērtības likumsakarīgi strauji pieaug, kas norāda arī uz poru veidošanās intensitāti. Tomēr tas arī ierobežo pielietojumu - ne augstākās temperatūrās kā aptuveni $600{ }^{\circ} \mathrm{C}$.

\section{Illītu mālu apstrāde to pielietošanas dažādošanai (ǵeopolimēru metode)}

Ir veikti relatīvi plaši pētījumi par illītu mālu ķīmisku, mehānisku, termisku un hidrotermālu apstrādi ar nolūku 'vājināt' vai 'sagraut' mālainā minerāla illīta struktūru, lai attīstītu keramikas materiālu izstrādi pie
Latvijas minerālās izejvielas eko-keramikas izstrādei 
pazeminātām temperatūrām, salīdzinot ar tradicionālām. Ir zināms [23], ka 1:1 kārtaino mālu minerālu (piemēram, kaolinīta) struktūru apstrādes rezultātā var izmainīt tādējādi, lai oktaedriski koordinētais alumīnijs mainītu koordināciju no 6 uz 4, veidojot tetraedrisku $\left[\mathrm{AlO}_{4}\right]$ grupējumu un līdz ar to kopēju 'amorfu' struktūras motīvu ar $\left[\mathrm{SiO}_{4}\right]^{4-}$. Lìdz ar šādu amorfas struktūras veidošanos, kaolinītu saturoši māli iegūst cietējošas/ cementējošas īpašības zemās $\left(<60^{\circ} \mathrm{C}\right)$ temperatūrās, uzrādot adekvātas mehāniskās īpašības. Illīti, 2:1 kārtainie mālu minerāli, šādām struktūras izmainām pakḷaujas ḷoti vāji. Un šo mālu apstrāde, it sevišḳi kīmiskā apstrāde ar sārmu, ietekmē tikai smilšaino un putekḷaino (karbonātus saturošo) frakciju tādējādi, ka ir iespējams ievērojami pazemināt, piemēram, būvkeramikas apdedzināšanas temperatūru, sasniedzot pietiekami augstus iegūtās keramikas spiedes izturības rādītājus [24]. 17. att. ir parādīta dažādi apstrādātu illītu mikrostruktūras izmaiṇas atkarībā no apstrādes veida. 18. att. ir parādīta keramikas paraugu, kas iegūti no ķ̄imiski apstrādāta illītu saturoša māla (Lažas atradne), spiedes izturības un šķietamā blīvuma izmaiṇas atkarībā no apdedzināšanas temperatūras un apstrādei pielietotā $\mathrm{NaOH}$ sārma koncentrācijas.

Ir redzams, ka ievērojamākas mikrostruktūras izmaiṇas ir $550-580{ }^{\circ} \mathrm{C}$ temperatūrā termiski apstrādātam illītam, kā arī ķīmiski ar $8 \mathrm{M} \mathrm{NaOH}$ apstrādātam illītam, kuros veidojas ceolīta grupas prizmatiski adatveidu minerāli $-\mathrm{Na}_{6}\left(\mathrm{AlSiO}_{4}\right)_{6} \cdot 4 \mathrm{H}_{2} \mathrm{O}$.

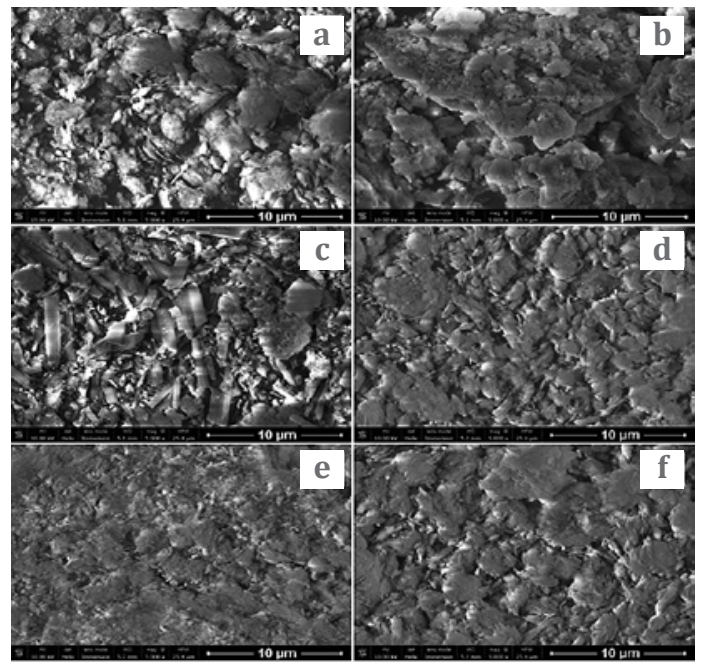

17. att. Dažādi apstrādātu illītu mikrostruktūru SEM attēli: (a) neapstrādāti illīts, (b) illīts apstrādāts ar $6 \mathrm{M} \mathrm{NaOH}$ šksīdumu, (c) illīts apstrādāts ar $8 \mathrm{M} \mathrm{NaOH}$ škīidumu, (d) $580^{\circ} \mathrm{C}$ temperatūrā apstrādāts illīts, (e) $72 \mathrm{~h}$ hidrotermāli apstrādāts illīts pie aptuveni $1 \mathrm{MPa}$ spiediena aptuveni $170^{\circ} \mathrm{C}$ temperatūras, (f) tas pats, bet apstrādes laiks ir $96 \mathrm{~h}$. 
No praktiskā viedokḷa keramikas paraugu, kas iegūti no ķīmiski apstrādāta māla, būtiskā iezīme ir spiedes izturības pieaugums jau pie $600{ }^{\circ} \mathrm{C}$ paraugu apdedzināšanas temperatūras. Jau tad šis lielums sasniedz būvkeramikai adekvātas vērtības, samazinoties arī škietamajam blīvumam.
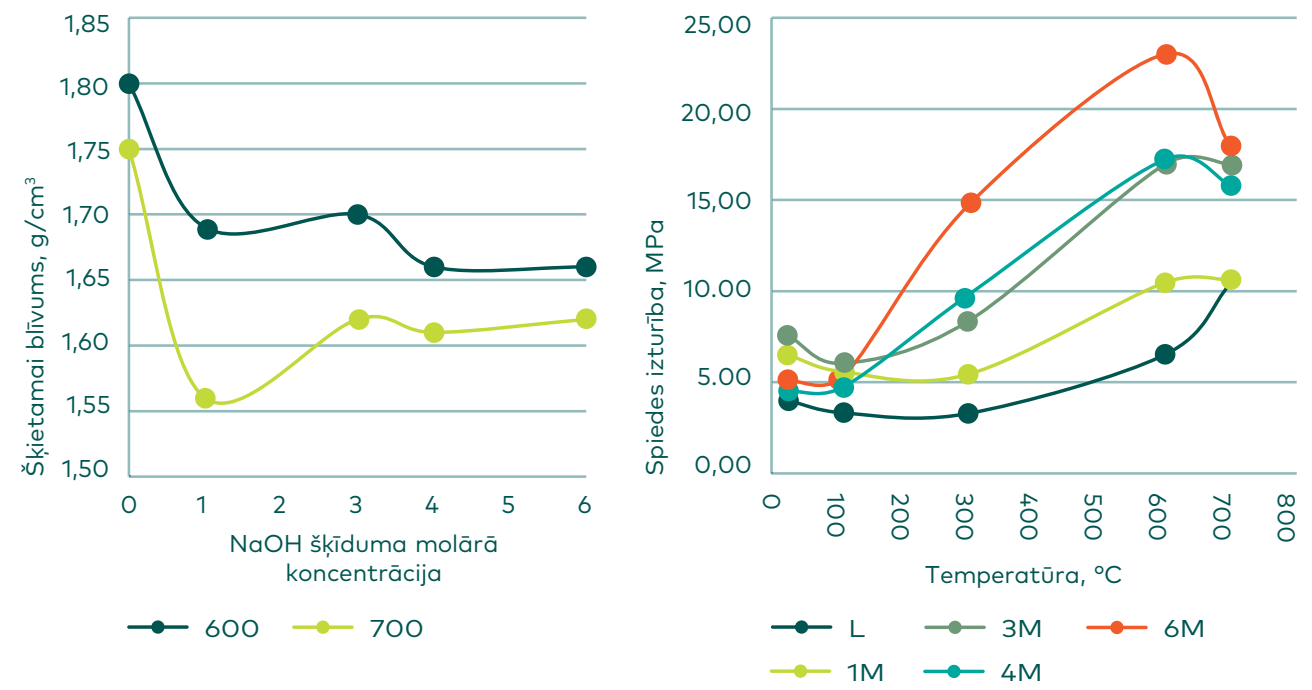

\section{Kopsavilkums}

Parādīta Kupravas atradnes mālu slānnu pielietošanas iespēja atkritumu deponēšanas vietu noblīvēšanai. Noteikts, ka māla slānna ūdens caurlaidība ir niecīga un ir $1,30 \cdot 10^{-7} \mathrm{~m} \cdot \mathrm{s}^{-1}$. Šì vērtība atbilst normām un ir zemāka par standartos norādīto.

Kupravas māla paraugu sorbcijas spējas pārbaudes notekūdeños, kas saistīti ar galvanisko tehnoloǵiju izmantošanu un satur kaitīgus jonus $\left(\mathrm{Cr}^{3+}, \mathrm{Cu}^{2+}, \mathrm{Zn}^{2+}\right)$ 1-1,5 mg/l lielās koncentrācijās, parāda, ka šo jonu koncentrācija šķīdumā pēc $24 \mathrm{~h}$ ir samazināta līdz 0,02-0,05 mg/l, kas ir zemāk par maksimāli piel̦aujamo koncentrāciju (aptuveni 0,1 mg/l).

Izmantota kompleksa pieeja Latvijas minerālo izejvielu (illītu mālu, dolomīta, kvarca smilšu) pielietošanai augsttemperatūras špinel̦u/ kordietīta kristāliskās fāzes saturošas blīvas vai porainas keramikas izstrādei. Parādīts, ka saķepināšanas temperatūrā $\geq 1200{ }^{\circ} \mathrm{C}$ atkarībā no konkrētās izejvielu kompozīcijas veidojas makroporas saturoša keramika ar tilpuma masu ap $1 \mathrm{~g} / \mathrm{cm}^{3}$ un zemu lineārās termiskās izplešanās koeficientu $1,0 \cdot 10^{-6}-3,0 \cdot 10^{-6}, \mathrm{~K}^{-1}$ atkarībā no izmantotās temperatūras. 
Savukārt blīva kordierīta keramika raksturojama ar augstu elastības modula vērtību (98 GPa), kas pakḷaujot paraugus 10 straujiem temperatūras maiṇas cikliem $1000{ }^{\circ} \mathrm{C} / 20{ }^{\circ} \mathrm{C}$ samazinājas līdz $65-70 \mathrm{GPa}$, kas saskaṇā ar ASTM standartu norāda uz augstu termiskā trieciena izturību.

Ir noteikts, ka illīti, kā arī illītu māli neveido tipiskus geopolimērus. Tomēr ir novērojama koncentrētu sārmu iedarbība uz illītu māliem. Parādīts, ka k̦īmiski apstrādātu illìtu mālu pielietojums keramikas izstrādei varētu būt perspektīvs, jo apstrādes rezultātā ievērojami samazinās apdedzināšanas temperatūra, vienlaicīgi sasniedzot pietiekami augstas spiedes izturības vērtības - aptuveni $20 \mathrm{MPa}$.

\section{Pateicības}

Darba izstrādē piedalījušies: bakalauranti Ilmārs Apsītis un Inga Raubiška; maǵistranti Karīna Zeiḷa, Artūrs Korovkins, Mārtiṇš Randers un doktorants Māris Rundāns

Pētījumi veikti, pateicoties ERAF -projekta 1.1.1.1/16/A/077, (RTU 2587) "Minerālu un sintētisko nanopulveru pielietojums keramikas modificēšanai un tās izstrādei” un Valsts pētījumu programmas “Vietējo resursu ilgtspējīga izmantošana - jauni produkti un tehnoloǵijas (NATRES un GEO)" apakšprojekta "Jauni keramikas materiāli un tehnoloǵijas" un "Zemes dzịlu resursu izpēte dabisko izejvielu dažādošanai un jaunu tehnoloǵiju izstrādei” (2010. g. - 2017. g.) finansējumam.

\section{LITERATŪRAS SARAKSTS}

[1] P. Muralt, "Environmentally motivated materials research in ceramics," In ICC2 Proceedings: Global Roadmap for Ceramics, 2008, p. 6.

[2] K. Halada and R. Yamamoto, "The Current Status of Research and Development on Ecomaterials around the World," MRS Bulletin, vol. 26, no. 11, pp. 871-879, Nov. 2001. https://doi.org/10.1557/mrs2001.227

[3] O. Umezawa, K. Halada, and Y. Shinohara, "Ecomaterials in the Global Eco-Society: Present Situation and Future Prospects," Materials Science Forum, vol. 555, pp. 1-7, 2007. https://doi.org/10.4028/www.scientific. net/msf.555.1

[4] G. Sedmale, I. Sperberga, U. Sedmalis, and Z. Valancius, "Formation of high-temperature crystalline phases in ceramic from illite clay and dolomite," Journal of the European Ceramic Society, vol. 26, no. 15, pp. 33513355, Jan. 2006. https://doi.org/10.1016/j.jeurceramsoc.2005.10.012

[5] G. Sedmale, I.Sperberga, A. Actins, and A. Patmalnieks, "Development of Mullite and Cordierite Crystalline Phases in Ceramic from Mixed Compositions," In Proc. of 1st Ceramics Congress, Global Roadmap - 2006, p. 8.

[6] G. Sedmale, I. Šperberga, A. Hmel̦ovs, and A. Celms, "Dabas aizsardzībai motivēti keramikas materiāli, pielietojot Latvijas minerālās izejvielas," Materiālzinātne un lietišķā k̦īmija, vol. 19, pp. 78-87, 2009. 
[7] DIN 18130-1:1998-05. Baugrund - Untersuchung von Bodenproben; Bestimmung des Wasserdurchlässigkeitsbeiwerts - Teil 1: Laborversuche.

[8] H. F. McMurdie and F. P. Hall, "Phase Diagrams for Ceramists: Supplement No. 1," Journal of the American Ceramic Society, vol. 32, no. s1, pp. 154164, Dec. 1949. https://doi.org/10.1111/j.1151-2916.1949.tb19765.x

[9] Н. А.Торопов, В. Барзаков, В. В. Лапин, “Диаграммы состояания силикатных систем," Leningrad, USSR: Наука, 1972.

[10] W. R. Foster, "Contribution to the Interpretation of Phase Diagrams by Ceramists," Journal of the American Ceramic Society, vol. 34, no. 5, pp. 151-160, May 1951. https://doi.org/10.1111/j.1151-2916.1951.tb11625.x

[11] J. Beresneva, and G. Sedmale, "Poru keramika no jauktiem izejvielu maisījumiem," In 51. RTU Studentu zinātniskās un tehniskās konferences materiāli, 2010, pp. 164-165.

[12] G.Sedmale, U. Sedmalis, I. Šperberga, and A. Korovkins, "Minerālo izejvielu pielietošanas pamatojums keramikas produktu un tehnologiju izstrādei," Materiālzinātne un lietišk kā ḳimija, vol. 24, pp. 26-29, 2011.

[13] G. Sedmale, I. Kuzṇecova, and U. Sedmalis, "Augsttemperatūras poru keramika no jaukta sastāva izejvielu maisījumiem," Materiālzinātne un lietiškā kịmija, vol. 26, pp.55-60, 2012.

[14] W. D. Nesse, "Introduction to Mineralogy," New York, NY: Oxford University Press, 2000.

[15] P. Rohan, K. Neufuss, J. Matějíček, J. Dubský, L. Prchlík, and C. Holzgartner, "Thermal and mechanical properties of cordierite, mullite and steatite produced by plasma spraying," Ceramics International, vol. 30, no. 4, pp. 597-603, Jan. 2004. https://doi.org/10.1016/j. ceramint.2003.07.004

[16] R. Goren, C. Ozgur, and H. Gocmez, "The preparation of cordierite from talc, fly ash, fused silica and alumina mixtures," Ceramics International, vol. 32, no. 1, pp. 53-56, Jan. 2006. https://doi.org/10.1016/j. ceramint.2005.01.001

[17] R. Goren, H. Gocmez, and C. Ozgur, "Synthesis of cordierite powder from talc, diatomite and alumina," Ceramics International, vol. 32, no. 4, pp. 407-409, Jan. 2006. https://doi.org/10.1016/j.ceramint.2005.03.016

[18] ASTM C1525 - 04(2013). Standard Test Method for Determination of Thermal Shock Resistance for Advanced Ceramics by Water Quenching.

[19] J. Zhou, Y. Dong, S. Hampshire, and G. Meng, "Utilization of sepiolite in the synthesis of porous cordierite ceramics," Applied Clay Science, vol. 52, no. 3, pp. 328-332, May 2011. https://doi.org/10.1016/j.clay.2011.02.001

[20] S. Ferrari, and F. Gualtieri, "The use of illitic clays in the production of stoneware tile ceramics," Applied Clay Science, vol. 32, no. 1-2, pp. 73-81, Apr. 2006. https://doi.org/10.1016/j.clay.2005.10.001

[21] U. Sedmalis, I. Šperberga, and G. Sedmale, "Simetrija un simetrisku lauku iedarbība,” Riga, Latvia: RTU izdevniecība, 2008.

[22] M. Rundans and I. Sperberga, "Porous Cordierite Ceramics from Natural Clays / Poraina kordierīta keramika no dabiskiem māliem," Materials 
Science and Applied Chemistry, vol. 32, no. 1, pp. 33-38, Jan. 2015. https:// doi.org/10.1515/msac-2015-0006

[23] K. J. D. MacKenzie, D. R. M. Brew, R. A. Fletcher, and R. Vagana, "Formation of aluminosilicate geopolymers from 1:1 layer-lattice minerals pretreated by various methods: a comparative study," Journal of Materials Science, vol. 42, no. 12, pp. 4667-4674, Jan. 2007. https://doi.org/10.1007/ s10853-006-0173-x

[24] G. Sedmale, M. Randers, M. Rundans, and V. Seglins, "Application of differently treated illite and illite clay samples for the development of ceramics," Applied Clay Science, vol. 146, pp. 397-403, Sep. 2017. https://doi. org/10.1016/j.clay.2017.06.016

Gaida Sedmale, Dr. habil. chem., asociētā profesore, vadošā pētniece. G. Sedmale ir vairāk kā 200 zinātnisko publikāciju autore stikla un keramikas ḳīmijas un tehnologijas jomā. Viṇa ir arī vairāk kā 50 Latvijas un Krievijas patentu autore. Pēdējo 20 gadu laikā viṇa ir pētījusi gan jaunus augsttemperatūras, gan tradicionālos keramiskos materiālus. Viṇa pasniedz studiju kursu "Smalkkeramikas kīmija un tehnologiija" un ir zinātniskā vadītāja bakalaura un maǵistra darbiem. E-pasts: gaida-maruta.sedmale@rtu.lv

ORCID: 0000-0003-2672-304X

Māris Rundāns ieguva maǵistra grādu k̦īmijas tehnoloǵijā 2012. g. (Rīgas Tehniskās universitāte, Materiālzinātnes un lietišķās k̦īmijas fakultāte). Pašlaik viṇš turpina studijas doktorantūras līmenī Rīgas Tehniskās universitātes Materiālzinātnes un lietišķās ḳimijas fakultātē. Viṇa zinātniskās interešu jomas ir augsttemperatūras keramika un to sintēzes metodes, pielietojot gan dabiskus, gan sintētiskus izejmateriālus.

E-pasts: maris.rundans@rtu.lv

ORCID: 0000-0002-5801-1146

Mārtiṇs Randers ir ieguvis maǵistra grādu k̦īmijas tehnologijā. M. Randers ir zinātniskais asistents Rīgas Tehniskās universitātes Silikātu materiālu institūtā. M. Randera zinātniskās interešu jomas ir mālu un keramisko materiālu izpēte.

E-pasts: martins.randers@inbox.lv

Ingunda Šperberga, Dr. sc. ing. (1998), asociētā profesore, vadošā pētniece. I. Šperberga ir vairāk nekā 75 zinātnisko publikāciju autore, to skaitā arī 5 monogrāfiju un mācību grāmatu autore. Viṇas interešu lokā ir kristalogrāfija, mineralogija, Latvijas derīgie izrakteṇi, kā arī silikātu fizikālā ḳīmija.

E-pasts: ingunda.sperberga@rtu.lv

ORCID: 0000-0002-7681-2203 
Andris Cimmers, Dr. sc. ing., vadošais pētnieks. A. Cimmera interešu lokā ir stikla pārklājumi (emaljas), zemtemperatūras keramika, poraina keramika, Latvijas derīgo izrakteṇu (māls, karbonātu grupas minerāli) izmantošana. Viṇš ir vairāk kā 40 zinātnisko publikāciju un Latvijas patentu autors.

E-pasts: andris.cimmers@rtu.lv

ORCID: 0000-0002-9141-1280

Gaida Sedmale, Māris Rundāns, Mārtiṇs Randers, Ingunda Šperberga, A. Cimmers.

\section{Mineral Raw Materials of Latvia for Development of Eco-Ceramics.}

The paper gives an insight into the possibilities to use Latvian mineral raw materials as a base or additives for the development of ceramic materials (ecomaterials) with different application aspects, including showing the possibility of optimizing the technological processes of these materials towards the reduction of their firing temperature, thereby reducing the release of harmful gaseous effluents into the environment.

The results of the works that are reported in the period were obtained from 2007 to 2017. The following studies are reviewed and analyzed: the use of untreated clay for the sealing of waste deposits; the use of partly dehydrated clay for sorption of $\mathrm{Cr}^{3+, 6+}, \mathrm{Zn}^{2+}$ and $\mathrm{Cu}^{2+}$, which have formed in galvanic processes; the development of porous high temperature ceramics from mixes of mineral raw materials and synthetic additives that provide a sufficient gas phase formation in the firing process and consecutively to form pores in obtained ceramic material; the use of illite clay additives to reduce the temperature of sintering of high temperature dense mechanical and thermally durable ceramics, as well as technological processes that ensure the production of porous, heat-insulating ceramic materials at reduced temperatures (geopolymer method). 